\title{
New Cholinesterase Inhibitor, Lipoic Acid-Nitrone Derivatives
}

\author{
Yun Mi Seo, Kang Hee Nam, Pill Seong Kang, Sung Bo Ko, Eugene Oh, \\ Min Tae Sung, Byoung Wook Choi, Bong Ho Lee, and Jeong Ho Park* \\ Deparment of Biotechnologv, Hanbat National Lniversitv. Daejeon $305-719$, Korea \\ ${ }^{*}$ E-mail: jhparkahanbatac.kr (J. H. Park): bhol 1ahanbat ac.hr (B. H. Lee) \\ COS Biotech, Inc., Daejeon Bio Ienture Town $+61-58$, Jeonmin-dong. Iuseong-gu. Daejeon $305-811$. Korea \\ Received November 25, 2006

\begin{abstract}
Lipoic acid (LA) is a multifunctional antioxidant against a variety of ROS. Nitrone acts as free radical spin trap screened as an antioxidant and inhibitors for cholinesterases. Even though the antioxidant effect of LA-nitrone derivatives was not improved. they turned out to be effective inhibitors of acetylcholinesterase (AChE) and butyrylcholinesterase (BuClE) in $\mu \mathrm{M}$ range.
\end{abstract} \\ and exhibits neuroprotective activity. Thus, LA-nitrone derivatives $(6,7,8$. and 9) were synthesized and
}

Key Words : Lipoic acid. Nitrone. Antioxidant. Cholinesterase inhibitor

\section{Introduction}

The reactive oxygen species (ROS) cause a lot of human diseases such as intestinal diseases. atherosclerosis. cardiac diseases. Alzheimer's disease. chronic neurodegenerative disorders. reperfusion injuries, respiratory disorders. inflammation, diabetes. cancer, and aging. ${ }^{1-4}$

Lipoic acid (LA) is a 1.2-dithiolane analogue and it is rapidly reduced to dihydrolipoic acid (DHLA) by cytosolic and mitochondrial dehydrogenases inside a cell. ${ }^{50}$ Both LA and its reduced form. DHLA. act as a multifunctional antioxidant against a variety of ROS ${ }^{5.6} \mathrm{LA}$ is a cofactor of enzymatic mitochondrial decarboxylation reactions and is an indispensable molecule for producing an adequate amount of ATP from glucose via the citric acid cycle. ${ }^{7}$ The other functions of LA are the assistant for regeneration and $d e$ now syntheses of endogenous antioxidants such as glutathione and $\alpha$-tocoperol, thioredoxin, and vitamin $C^{8}$ the chelator for metal ions such as iron, ${ }^{9.10}$ and the repairing agent for oxidatively damaged macromolecules. ${ }^{1-13}$ LA exhibits anti-anyloidogenicity by inhibiting the formation and extension of fibrillar $\beta$ anyloid (fA $\beta \mathrm{L}-40$ ) and $\mathrm{fA} \beta$ (l42 ) as well as destabilizing $\mathrm{fA} \beta$ at $\mathrm{pH} 7.5 \mathrm{in} \mathrm{vith.}^{14}$

Since LA has many benign effects. it is used as a dietary supplement and applied to medical treatments such as diabetes, ${ }^{15.17}$ ischemia-reperfusion injury. ${ }^{18}$ cataract formation. ${ }^{16}$ neurodegeneration. ${ }^{2(1.23}$ and hypertension ${ }^{\hat{3}}$ LA also decreases exhaled nitric oxide concentrations in anesthetized endotoxenic rats. ${ }^{-4-}$

Due to its lipophilicity, LA easily crosses over the bloodbrain barrier and results in accumulation in all neuronal cell types. ${ }^{-5}$ Many LA derivatives such as LA-L-dopa and LAdopanime. ${ }^{26}$ LA-Trolox (a water-soluble analogue of vitanin E) ${ }^{27}$ LA-anthiphilic hybrid of $\alpha$-phenyl- $N$-tert-butyl nitrone (PBN) (PBNLP), ${ }^{3 s}$ LA-nitric oxide synthase inhibitors, and LA- $N$-alkyl-substituted morpholine ${ }^{31}$ have been synthesized to improve their biological activities and to give a synergic effect. LA dimers have been synthesized as an oral auxiliary drug for type 2 diabetic patients. ${ }^{31}$ The activity of LA-chroman analogues were evaluated against reperfusion arrhy tlumias. ${ }^{32}$

Nitrone-based free radical spin traps such as $\alpha$-phenyl- $N$ tert-butyl nitrone (PBN) exhibit neuroprotective activity. ${ }^{33.34}$ Recently. Durand et al. reported the synthesis of a novel series of amphiphilic glycosylated nitrones derived from PBN for antioxidant activity ${ }^{28}$

In the present paper, we report the synthesis of the covalent LA-nitrone derivatives between LA and the simple nitrones $(1,2.3$. and 4$)$ and their biological activities.

\section{Results and Discussions}

Nitrone-based free radical spin traps such as $\alpha$-phenyl- $N$ tert-butyl nitrone (PBN) have been developed as an antioxidant. $^{32,24}$ Therefore, the novel compounds coupled between LA and nitrone functional group would expect to show synergic effects as an antioxidant. The nitrone compounds in Figure 1 have been synthesized by COS Biotech. Inc. Four nitrone compounds were directly coupled to lipoic acid without any further purification. Nitrone 1, $\mathbf{3}$, and + were coupled to LA with CDMT/NMM condition at room temperature to result in 5 ( $71 \%$ isolated yield), 7 ( $42 \%$ isolated yield). and 8 ( $44 \%$ isolated yield). respectively. The coupling reaction between nitrone 2 and LA with EDCI/ DMAP condition resulted in 6 with $50 \%$ isolated yield (Figure 2)

The radical scavenging effect and cholinesterase $(\mathrm{ChE})$
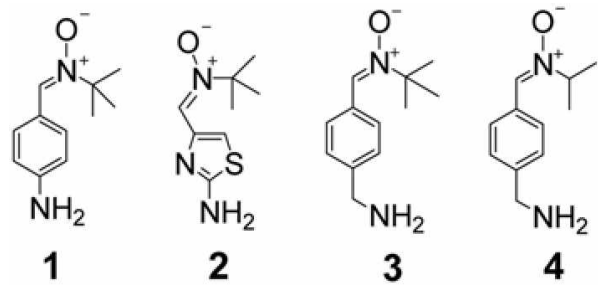

Figure 1. Nitrone compounds for coupling with LA. 


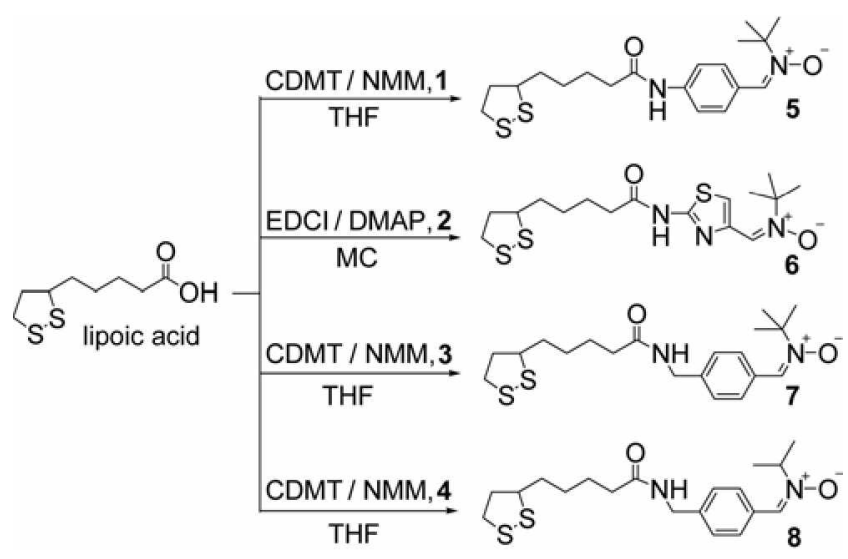

Figure 2. Synthesis of LA-Nitrone Compounds.

Table 1. Biological activity of LA-nitrone compounds

\begin{tabular}{|c|c|c|c|c|c|}
\hline \multirow{2}{*}{$\begin{array}{c}\text { sample } \\
\text { concentration } \\
(\mathrm{mg} / \mathrm{mL})\end{array}$} & \multirow{2}{*}{$\frac{\Delta \mathrm{A}(\%)}{0.1}$} & \multicolumn{2}{|c|}{$\begin{array}{c}\mathrm{ACl} E \\
\text { inhibition }(\%)\end{array}$} & \multicolumn{2}{|c|}{$\begin{array}{c}\text { BuClE } \\
\text { inhibition }(\%)\end{array}$} \\
\hline & & 0.1 & 0.01 & 0.1 & 0.01 \\
\hline lipoic acid & 64.9 & 10.5 & 0.0 & 14.7 & 5.0 \\
\hline 1 & 13.2 & 38.8 & 0.0 & 17.6 & 15.9 \\
\hline 2 & 22.4 & 45.8 & 5.8 & 38.2 & 9.3 \\
\hline 3 & 25.4 & 74.2 & 0.0 & 69.4 & 10.8 \\
\hline 4 & 25.5 & 55.6 & 0.0 & 24.3 & 11.3 \\
\hline 5 & 19.1 & 58.0 & 24.9 & 56.7 & 20.7 \\
\hline 6 & 17.5 & 93.7 & 66.9 & 83.4 & 37.6 \\
\hline 7 & 25.4 & 93.0 & 64.9 & 61.6 & 13.5 \\
\hline 8 & 26.9 & 67.1 & 29.9 & 70.0 & 19.4 \\
\hline
\end{tabular}

$\Delta A$ is the absorbance difference at $518 \mathrm{~mm}$

inhibitory effect of LA-nitrone compounds were tested and the results are shown in Table 1. The antioxidative effect of LA-nitrone compounds was checked by DPPH (1.1-diphenyl-2-picryllyydarzyl) assay. in which radical scavenging effect of DPPH was expressed as percentage decrease $[\Delta \mathrm{A}(\%)]$ with respect to control values. There is no improvement in $\triangle \mathrm{A}$ values of LA-nitrones compared to the corresponding nitrones. Also $\Delta \mathrm{A}$ values of LA-nitrones were much less than that of lipoic acid. The inhibition effects of AChE and $\mathrm{BuChE}$ were checked by the Ellman's coupled enzyme assay. ${ }^{3:}$

Since the inhibition effect of compound 1-8 on ChEs was decreased at the low concentration. there is no inhibitory: saturation effect. Compound 6 and 7 are the most potent inhibitors of $\mathrm{AChE}$ among the nine compounds. Compound 3.6 and 8 are the most potent inhibitors of $\mathrm{BuChE}$. Neither lipoic acid nor nitrones inhibited cholinesterases as effective

Table $2 . \mathrm{IC}_{50}$ value of the LA-nitrone compounds $3,6,7$ and 8

\begin{tabular}{ccc}
\hline Compound & $\mathrm{IC}_{50}$ for $\mathrm{AClE}(t, \mathrm{M})$ & $\mathrm{IC}_{\mathrm{s} 0}$ for $\mathrm{BuClE}(\mu \mathrm{M})$ \\
\hline 3 & 278.8 & 247.2 \\
6 & 19.1 & 46.4 \\
7 & 19.1 & 114.5 \\
8 & 128.7 & 128.5 \\
\hline
\end{tabular}

as LA-nitone compound 6 . IC $\mathrm{C}_{51}$ values for 3, 6, 7 and 8 were measured for $\mathrm{AChE}$ and $\mathrm{BuChE}$ (Table 2). Compound 6 shows the thiazole in the nitrone moiety is better than phenyl ring for binding to the enzyme active site.

\section{Conclusions}

Four nitrone compounds $(1,2,3$, and 4$)$ are covalently connected to LA to give LA-nitone derivatives $(5,6,7$, and 8). IC so values of 6 are 19.1 and $46.4 \mu \mathrm{M}$ for $\mathrm{AChE}$ and BuChE. respectively: Growing evidence suggests that the neurobiological basis of senile dementia in Alzheimer's disease (AD) and related dementias is a loss of cholinergic neurons. It results in decline in acetylcholine $(\mathrm{ACh})$ in brain regions which regulate behavioral and emotional responses. This cholinergic deficit can be partly corrected by inhibiting ChEs. In healthy brain. $\mathrm{AChE}$ predominates $(80 \%)$ and $\mathrm{BuChE}$ is considered to play a minor role in regulating brain $\mathrm{ACh}$ levels. In the $\mathrm{AD}$ brain. $\mathrm{BuChE}$ activity rises while $\mathrm{AChE}$ activity remains unchanged or declines. Therefore. both enzymes are likely to have involvement in regulating $\mathrm{ACh}$ levels and represent legitimate therapeutic targets to ameliorate the cholinergic deficit. Recent researches have thought that dual inhibitors of $\mathrm{AChE}$ and $\mathrm{BuChE}$ may provide more sustained efficacy over the course of $A D$ and may help to slow disease progression. ${ }^{36}$ Further investigations will be carried out to check the activity against AD with LAnitrone compounds.

\section{Experimental Section}

${ }^{1} \mathrm{H}-\mathrm{NMR}$. and ${ }^{13} \mathrm{C}-\mathrm{NMR}$ spectra were recorded on a varian Mercury 400 ( $400 \mathrm{MHz}$ ) and Bruker ARX-300 (300 $\mathrm{MHz}$ ). Melting points were determined on SMP3. Highresolution mass spectra (HRMS) were recorded on a JMS700 Mstation mass spectrometer under fast atom bombardment $(\mathrm{FAB})$ conditions with nitrobenzyl alcohol (NBA) as the matrix in the Korea Basic Science Institute (Seoul). Korea. Flash column chromatography was performed using E. Merck silica gel $(60$. particle size $0.040-0.063 \mathrm{~mm})$. Analytical thin layer chromatograply (TLC) was performed using pre-coated TLC plates with silica Gel $60 \mathrm{~F} 254$ (E. Merck). All of the synthetic reactions were carried out under argon atmosphere with dry solvent. unless otherwise noted. Tetrahydrofuran (THF) was distilled from sodium/benzophenone immediately prior to use and methylene chloride $\left(\mathrm{CH}_{2} \mathrm{Cl}_{2}\right)$ was dried from calcium hydride. All chemicals were reagent grade unless othervise specified. The lipoic acid. CDMT. NMM. and EDCI were obtained from SigmaAldrich Chemical Co and used without purification. The nitrones. 1 2.3. and 4, were obtained from Cos Biotech Inc. (Daejeon).

Free radical scavenging activity. The DPPH (1,1-Diphenyl-2-picrylhydarzyl) radical scavenging effect was carried out according to the method first employed by M.S. Blois. The $100 \mu \mathrm{L}$ of sample solution was added to $900 \mu \mathrm{L}$ of DPPH solution in ethanol $\left(1.01 \times 10^{-4} \mathrm{M}\right)$. After incuba- 
tion at room temperature for $30 \mathrm{~min}$, the absorbance of this solution was determined at $518 \mathrm{~nm}$ using spectrophotometer and the remaining DPPH was calculated. All experiments were carried out in triplicate. Results were expressed as percentage decrease with respect to control salues. The each fraction was evaluated at the final concentration at $100 \mu \mathrm{g} /$ $\mathrm{mL}$ in the assay mixture.

Cholinesterase assay. ChE-catalyzed hydrolysis of the thiocholine esters was monitored by following production of the anion of thiocholine at $412 \mathrm{~mm}$ by the Ellmans coupled assay. Assays were conducted on HP8452A or HP8453A diode array UV-visible spectrophotometers and the cell compartments were thermostated by circulating water or Peltier temperature controller. respectively. Acetylthiocholine (ATCh) and butyrylthiocholine (BuTCh) were used as substrates for $\mathrm{AChE}$ and $\mathrm{BuChE}$, respectively.

5-[1,2]Dithiolan-3-y]-pentanoic acid phenylamido- $t$ butyl nitrone (5). Lipoic acid (100 $\mathrm{mg} .0 .48 \mathrm{mmol}$ ) was dissolved in THF. CDMT (102 $\mathrm{mg} .0 .58 \mathrm{mmol}$ ) and NMM (147 $\mathrm{mg} .1 .46 \mathrm{mmol}$ ) were added to the lipoic acid solution. The mixture was stirred for $1 \mathrm{~h}$ and then nitrone 1 (93 $\mathrm{mg}$. $0.48 \mathrm{mmol}$ ) was added to the solution at room temperature. The reaction mixture was stirred for $24 \mathrm{~h}$ at room temperature. The reaction mixture was poured into water. The resultant solution was extracted with methylene chloride three times. The combined organic extracts were treated with brine and dried over anhydrous $\mathrm{MgSO}_{4}$. After the organic solvent was removed under vacuum. the crude product was then purified by flash cluromatography using hexane/ethylacetate (1:3) as the eluant to give 5 as a white solid ( $130 \mathrm{mg}$. $71 \%$ yield).

mp 148-150 ${ }^{\circ} \mathrm{C}:{ }^{1} \mathrm{H} \mathrm{NMR}\left(\mathrm{CDCl}_{3,} 400 \mathrm{MHz}\right): 8.27(\mathrm{~d}, J=$ $9.2 \mathrm{~Hz} .2 \mathrm{H}) .7 .59$ (d. $J=8.8 \mathrm{~Hz} 2 \mathrm{H}) .7 .50$ (s. $2 \mathrm{H}) .3 .57(\mathrm{~m}$. lH) $3.19(\mathrm{~m}, 2 \mathrm{H}), 2.45(\mathrm{~m}, 3 \mathrm{H}), 1.87(\mathrm{~m}, \mathrm{lH}) .1 .66(\mathrm{~m}, 6 \mathrm{H})$. 1.58 (s. 9H). 1.61 (s. 9H). $1.50(\mathrm{~m} .2 \mathrm{H}):{ }^{13} \mathrm{C} \mathrm{NMR}\left(\mathrm{CDCl}_{3}\right.$. $100 \mathrm{MHz}) 172.43 .140 .12,129.97,129.56,119.05,70.66$. $56.54,40.44,38.69,37.70,34.85,29.06,28.52,25.33$. HRFAB-MS. Exact mass calcd. for $\mathrm{C}_{19} \mathrm{H}_{29} \mathrm{~N}_{2} \mathrm{O}_{2} \mathrm{~S}_{2}(\mathrm{M}+\mathrm{H})$ : 381.1665 , found: 381.1667 .

5-[1,2]Dithiolan-3-y]-pentanoic acid thiazol-2-ylamido$t$-butyl nitrone (6). Lipoic acid (300 $\mathrm{mg} .1 .44 \mathrm{mmol}$ ) was dissolved in methylene chloride. EDCI (335 mg. $1.75 \mathrm{mmol}$ ) and DMAP (18 $\mathrm{mg} .0 .15 \mathrm{mmol}$ ) were added to the lipoic acid solution. The mixture was stirred for $15 \mathrm{~min}$ and then nitrone 2 (289 $\mathrm{mg} .1 .45 \mathrm{mmol}$ ) $\mathrm{mg}$ was added to the solution at room temperature. The reaction mixture was stirred for 24 $h$ at room temperature. The reaction mixture was poured into water. The resultant solution was extracted with methylene chloride three times. The combined organic extracts were treated with brine and dried over anhydrous $\mathrm{MgSO}_{4}$. After the organic solvent was removed under vacuun. the crude product was then purified by flash chromatography using ethylacetate as the eluant to give 6 as a white solid (280 mg. $50 \%$ yield).

mp 155-157 ${ }^{\circ} \mathrm{C}:{ }^{1} \mathrm{H} \mathrm{NMR}\left(\mathrm{CDCl}_{3 .} 400 \mathrm{MHz}\right) 8.79(\mathrm{~s}, 2 \mathrm{H})$. $7.81(\mathrm{~s}, 1 \mathrm{H}), 3.57(\mathrm{~m} . \mathrm{HH}) .3 .14(\mathrm{~m}, 2 \mathrm{H}), 2.46(\mathrm{~m} .3 \mathrm{H}) .1 .92$ (m. 1H). $1.82(\mathrm{~m}, 4 \mathrm{H}), 1.72(\mathrm{~s}, 9 \mathrm{H}), 1.68(\mathrm{~m}, 2 \mathrm{H})$ (Figure
19): ${ }^{12} \mathrm{C} \mathrm{NMR}\left(\mathrm{CDCl}_{3} .100 \mathrm{MHz}\right) 170.28,156.53 .141 .38$. $125.58,118.09,70.60,56.48,40.53,38.79,36.42,34.86$. 29.02. 28.47, 24.94: HR-FAB-MS. Exact mass calcd. for $\mathrm{C}_{16} \mathrm{H}_{26} \mathrm{~N}_{3} \mathrm{O}_{2} \mathrm{~S}_{3}(\mathrm{M}+\mathrm{H}): 388.1182$, found: 388.1190 .

5-[1,2]Dithiolan-3-yl-pentanoic acid benzylamido-tbutyl nitrone (7). Following the procedure for the preparation of 5.7 was obtained from lipoic acid (200 $\mathrm{mg} .0 .97$ numol) and 3 (200 $\mathrm{mg} .0 .97 \mathrm{mmol}$ ) as a white solid (160 mg. $42 \%$ yield).

mp 106-108 ${ }^{\circ} \mathrm{C}:{ }^{1} \mathrm{H}$ NMR $\left(\mathrm{CDCl}_{3}, 400 \mathrm{MHz}\right) 8.25$ (d, $J=$ $8.4 \mathrm{~Hz}, 2 \mathrm{H}$ ). 7.53 (s. 1H). 7.31 (d. $J=8.4 \mathrm{~Hz}, 2 \mathrm{H}), 5.79(\mathrm{~m}$. $1 \mathrm{H}), 4.47(\mathrm{~d}, J=5.6 \mathrm{~Hz}, 2 \mathrm{H}), 4.04(\mathrm{~s}, 1 \mathrm{H}) .3 .58(\mathrm{~m}, 1 \mathrm{H})$. $3.12(\mathrm{~m}, 2 \mathrm{H}), 2.42(\mathrm{~m}, 1 \mathrm{H}), 2.22(\mathrm{t}, 2 \mathrm{H}), 1.95(\mathrm{~m}, 1 \mathrm{H}), 1.72$ (m. 6H). $1.61(\mathrm{~s} .9 \mathrm{H}) .1 .51(\mathrm{~m}, 4 \mathrm{H}):{ }^{13} \mathrm{C}$ NMR $\left(\mathrm{CDCl}_{3} .100\right.$ $\mathrm{MHz})$ 172.63, 140.53, 130.44, 129.62, 129.28, 127.90. $71.09,56.64,43.64,40.51,38.75,36.74,34.89 .29 .15,28.62$. 25.67: HR-FAB-MS. Exact mass calcd for $\mathrm{C}_{201} \mathrm{H}_{31} \mathrm{~N}_{2} \mathrm{O}_{2} \mathrm{~S}_{2}(\mathrm{M}$ $+\mathrm{H}): 395.1821$, found: 395.1824 .

5-[1,2]Dithiolan-3-yl-pentanoic acid benzylamido-isopropyl nitrone (8). Following the procedure for the preparation of 5.8 was obtained from lipoic acid $(300 \mathrm{mg}$. $1.45 \mathrm{nmol})$ and $4(279 \mathrm{mg} .1 .45 \mathrm{mmol})$ as a white solid (24l mg. $44 \%$ yield).

mp $111-113^{\circ} \mathrm{C}:{ }^{1} \mathrm{H}$ NMR $\left(\mathrm{CDCl}_{3} .400 \mathrm{MHz}\right) 8.21$ (d. $J=$ $8.0 \mathrm{~Hz}, 2 \mathrm{H}) .7 .43$ (s. $1 \mathrm{H}) .7 .31(\mathrm{~d} . J=8.2 \mathrm{~Hz}, 2 \mathrm{H}) .5 .80(\mathrm{~m}$. $1 \mathrm{H}), 4.47(\mathrm{~d} . J=6.0 \mathrm{~Hz}, 2 \mathrm{H}), 4.21(\mathrm{~m}, 1 \mathrm{H}) .3 .56(\mathrm{~m}, 1 \mathrm{H})$. $3.16(\mathrm{~m}, 2 \mathrm{H}), 2.44(\mathrm{~m}, 1 \mathrm{H}), 2.24(\mathrm{t}, 2 \mathrm{H}), 1.89(\mathrm{~m}, 1 \mathrm{H}), 1.65$ $(\mathrm{m}, 6 \mathrm{H}), 1.47$ (d. $6 \mathrm{H}){ }^{13} \mathrm{C}$ NMR $\left(\mathrm{CDCl}_{3} .100 \mathrm{MHz}\right) 172.65$, $140.61,131.69 .130 .11,129.05,127.93,68.08,56.64,43.63$. $40.51,38.75,36.72,34.89,29.16,28.62,25.67,21.20$ : HRFAB-MS. Exact mass calcd for $\mathrm{C}_{19} \mathrm{H}_{29} \mathrm{~N}_{2} \mathrm{O}_{2} \mathrm{~S}_{2}(\mathrm{M}+\mathrm{H})$ : 381.1665 , found: 381.1667

Acknowledgements. We wish to thank the Korea Institute of Industrial Teclunology Evaluation \& Planning (ITEP) for the financial support through the Advanced Material Research Center for Better Environment (AMAREN) at Hanbat National University (HNU). This research was also supported by the Program for the Training of Graduate Students in Regional Innovation which was conducted by the Ministry of Conmerce Industry and Energy of the Korean Government.

\section{References}

1. Richardson, J. S. Am. X.Y. Acad. Sci. 1993, 695. 73-76.

2. Ames. B. N.: Shigenaga. M. K.: Hagetl. T. M. Proc. Katl Acad. Sci. L.S.A. 1993. 90.7915-7922.

3. Kontos. H. A. Chent. Biol. Int 1989. 72. 229-255.

4. Andersson. C.: Halleberg. A.: Hogberg. T. In Actrances in Dntg Research: Testa. B. A.. Meyers. U. A.. Eds.: Academic: London. 1997: p 64.

5. Evans. J. L.: Goldtine, I. D. Diabetes Techol. Ther: 2000. 2. 401 413.

6. Scott. B. C.: Amoma. O. I.: Evans. P. J.: ONeill. C.: Van der. V: Cross. C. E.: Trischler. H: Halliwell. B. Fre' Rad Res. 1994. 20. 119-133.

7. Randle. P. J. Diabetes 1 Ketab. Rev 1998. 14. $263-283$.

8. Deneke. S. M. Cwm Top. Cell Regul. 2000, $36,151-180$. 
9. Suh. J. H.: Zhu. B. Z.: deSzoeke. E.: Frei. B.: Hagen. T. M. Redox Rep. 2004. 9.57-61.

10. Matsugo. S.: Yan. L. J.: Han. D.: Trischer. H. J.: Packer. L. Biochent. Biophns. Res. Commm. 1995. 208.161-167.

11. Biewenga, G. P.: Haenen, G. R: Bast. A. A. Gen. Phamacol. 1997, 29,315-331.

12. Packer L.: Witt, E. H.: Tritschler, H. I. Free Rad Biol. Med. 1995. 19.227-250

13. Han. D.: Handleman. G.: Marcocci. L.: Sen. C. K.: Roy. S.: Kobuchi. H.: Tritschler. H. J.: Flohe. L.: Packer. L. Bio. Factors $1997,6,321-338$

14. Ono. K.: Hirohata, M.: Yamada. M. Biochem. Biophns. Res. Conm. 2006, 341, 1046-1052

15. Packer. L.: Witt. E. H.: Tritschler. H. J. Free Rad Biol. Med 1995. 19. $227-250$

16. Biewenga. G. P.: Haenen. G. R. M. M.: Bast. A. Gen. Phamac. $1997,29,315-331$

17. Borcea, V: Nourooz-Zadeh, I.: Wolff. S. P: Klevesath, M.: Hofmanu. M.: Urich. H.: Wald. P.: Ziegler. R.: Tritshler. H.: Halliwell. B.: Nawroth. P. P. Free Rad Biol. Med 1999. 26. 1495-1500.

18. Freisleben. H. J. Toxicologv 2000. 148. 159-171.

19. Maitra. I.: Serbinova. E.: Trischler. H.: Packer. L. Free Rad. Biol. Hed. 1995, 18. 823-829

20. Packer, L.: Trischler, H. Wessel, K. Free Rad Biol. Mad. 1997. 22. 359-378

21. Farr. S. A.: Poon. H. F.: Dogrukol-Ak. D.: Drake. J.: Banks. W. A.: Eyerman. E.: Buttertield. D. A.: Morley. J. E. J. Netrochem. 2003. 84. 1173-1183

22. Hager K: Marahrens, A.: Kenklies. M: Riederer. P.: Munch, G. Arch. Gerontol Geriatr 2001. 32, 275-282.

23. Midaouri. A. E.: Elimadi, A.: Wu. L.: Haddad, P. S.; de Champlain. I. Am. J. Hypertens. 2003. I6. 173-179.
24. De Marco. V. G.: Bosanquet. I. P.: Rawani. V. R.: Skimnning. J W. Tascular Phamacology 2005. $+3.404-410$.

25. Packer. L.: Trischler. H.: Wessel. K. Free Rad. Biol. Med 1997. 22. 359-378.

26. Di Stefano, A.; Sozio. P.: Cocco. A.: Iannitelli. A.: Santucei. E: Costa. M.: Pecci, L.: Nasuti. C.: Cantalamessa, F; Pinnen, F. d. Hed. Chem. 2006, Web 01:26.

27. Koufaki. M.: Calogeropoulou. I.: Detsi. A.: Roditis. A.: Kourounakis. A. P.: Papazafiri. P.: Tsiakitzis. K.: Gaitanaki. C.: Beis. I.: Kourounakis. P. N. J. Med Chem. 2001. H. $4300-4303$.

28. (a) Durand, G.: Polidori. A.: Salles. J.-P.: Pucci, B. Bioorg. Med. Chem. Lett. 2003. 13, 859-862. (b) Durand, G; Polidori, A.; Salles. J. P; Prost, M; Durand, P; Pucci, B. Bioorg. 1/ed. Chem. Lett. 2003. 13. 2673-2676.

29. Harnett. J. J.: Auguet. M.: Viossat. I.: Dolo. C.: Bigg. D.: Chabrier. P.-E. Bicorg. Hed. Chem. Lett 2002. 12. 1439-1442.

30. Guillonneau, C.: Charton, Y.: Ginot. Y.M; Fouquier-d Heroukl. M.-V; Bertrand. M: Lockhart, B.; Lestage. P.: Goldstein. S. Ew: J. Hed. Chem. $2003,38.1-11$.

31. Gruzmant. A.: Hidmi. A.: Katzhendler. J.: Abdalla Haj-Yehie. A.: Sasson1. S. Bioorg. Med Chent. Lett. 2004. 12. 1183-1190.

32. Koufaki. M.: Detsi. A.: Theodorou. E.: Kiziridi. C.: Calogeropoulou. T.: Vassilopoulos, A.: Kourounahis, A. P.; Rekia. E.: Kourounakis, P. N.; Gaitanaki. C.: Papazafiri, P. Bioorg. Hed. Chem. 2004, 12. $4835-4841$

33. Floyd. R. A. FASEB J. 1990. 4. 2587-2597.

34. Floyd. R. A.: Hensley. K.: Forster. M. J.: Kelleher-Andersson. J. A.: Wood. P. L. Hech Aging Dev: 2002. 123, 1021-1031.

35. Ellman. G. L.; Coutney, K. D.; Andres. V. Jr.: Featherstone. R. M. Biochem. Pharmacol 1961. 7, 88-95.

36. Basran. J; Mewies. M.: Mathews, F. S.: Scrutton, N. S. Biochem $1997,36,1989-1998$. 